\title{
Well Water Consumed and Urolithiasis in Gedangsari Subdistrict, Yogyakarta
}

\section{Konsumsi Air Sumur dengan Urolitiasis di Kecamatan Gedangsari, Yogyakarta}

\author{
Sulistyawati, Fardhiasih Dwi Astuti, Ruri Trisasri, Asep Rustiawan
}

Faculty of Public Health, Ahmad Dahlan University, Yogyakarta, Indonesia

\begin{abstract}
The land in Gedangsari Subdistrict area composes of limestone. Many local people consume drinking water from wells that contain high levels of calcium. Many people suffer from urolithiasis. This study aimed to describe calcium or $\mathrm{Ca}(\mathrm{OH})_{2}$ distribution in the well water and explain its relation with urolithiasis incidence. This study was conducted in Gedangsari Subdistrict, Gunung Kidul District from July to November 2013. The study was cross sectional confirmed with titration test in laboratory. Samples were 94 wells of 3,849 well population as selected randomly. Criteria of sample selection included wells used for drinking by the population aged older than 30 years already, with less than 15 meter of depth. Laboratory test of $\mathrm{Ca}(\mathrm{OH})_{2}$ level was conducted by titration. Suspect urolithiasis was clinically diagnosed by doctor and data analysis used chi-square test. Results showed relation between water hardness and urolithiasis (RP $=2.27$ ), although statistically not significant. In conclusion, there was no relation between mineral water consumption, age, and length of stay with urolithiasis incidence in Gedangsari Subdistrict, Gunungkidul District.
\end{abstract}

Keywords: Urolithiasis, water hardness, well water

\section{Abstrak}

Tanah di wilayah Kecamatan Gedangsari mengandung batuan kapur. Masyarakat di daerah ini banyak yang mengkonsumsi air minum dari sumur gali yang mengandung kadar kalsium tinggi, dan banyak yang menderita urolitiasis. Penelitian ini bertujuan untuk mendapatkan gambaran distribusi kalsium atau $\mathrm{Ca}(\mathrm{OH})_{2}$ pada air sumur dan menjelaskan hubungannya dengan kejadian urolitiasis. Penelitian dilakukan di Kecamatan Gedangsari, Kabupaten Gunungkidul selama Juli sampai November 2013. Penelitian dilakukan secara potong lintang dengan konfirmasi uji titrasi di laboratorium. Sejumlah 94 sampel sumur dipilih secara acak dari populasi 3.849 sumur. Kriteria pemilihan sampel adalah sumur gali yang telah digunakan untuk minum oleh penduduk berusia lebih dari 30 tahun, dengan kedalaman kurang dari 15 meter. Pemeriksaan laboratorium kadar kalsium dilakukan dengan titrasi. Dugaan urolitiasis didiagnosis melalui pemeriksaan klinis oleh dokter. Data dianalisis dengan uji kai kuadrat. Hasil analisis menunjukkan hubungan antara kesadahan air dengan urolitiasis (RP= 2.27) namun tidak bermakna secara statistik. Konsumsi air putih, usia, dan lama tinggal tidak berhubungan dengan kejadian urolitiasis di Kecamatan Gedangsari Kabupaten Gunungkidul.

Kata kunci: Urolitiasis, kesadahan air, air sumur

How to Cite: Sulistyawati, Astuti FD, Trisasri R, Rustiawan A. Well water consumed and urolithiasis in Gedangsari Subdistrict, Yogyakarta. Kesmas: National Public Health Journal. 2016; 11 (1): 26-31. (doi:10.21109/kesmas.v11i1. 1165)
Correspondence: Sulistyawati, Faculty of Public Health, Ahmad Dahlan University, Prof. Dr. Soepomo Street, Janturan, Warungboto, Yogyakarta, 55164, Phone:+62274563515, e-mail: sulistyawatisuyanto@gmail.com

Received: January $18^{\text {th }} 2016$

Revised: June $6^{\text {th }} 2016$

Accepted: July $14^{\text {th }} 2016$ 


\section{Introduction}

Water is a vital part of human life, and in all facets of life including for preparing food, hygiene and sanitation. ${ }^{1}$ Water hygiene use will determine the human health who consume. Several studies suggest that drinking at least 2 liters of water per day is effective to reduce the risk of urolithiasis because it will smooth the urine flow and prevent deposit forming in the kidneys. ${ }^{2,3}$ Water hardness is the term used for water containing cathions that cause hardness. ${ }^{4}$ In general, the hardness is caused by the presence of metals or monovalent cathions such as Iron (Fe), Strontium (Sr), Manganes (Mn), Calcium (Ca), and Magnesium $(\mathrm{Mg})$, although the main cause of hardness are calcium $\left(\mathrm{Ca}^{2+}\right)$ and magnesium $\left.\left(\mathrm{Mg}^{2+}\right)\right)^{1,2}$ Hardness is often found in the water from the ground or in the area where the land contains salt and chalk deposits. ${ }^{5}$

Whitewash is said as hard water because it contains $\mathrm{Ca}(\mathrm{HCO})$ and $\mathrm{Mg}(\mathrm{HCO})_{2}$ elements and flows through calcareous soils. Maximum hardness allowed is $500 \mathrm{mg} / \mathrm{l}$, consuming water that exceed the threshold may cause health problems. The impact of hard water to health includes the formation of urinary stones (urolithiasis). ${ }^{6}$

Gedangsari Subdistrict in Gunung Kidul District is a subdistrict where majority of its territory composed of limestone structure. The people living in this region, in the long term may be affected by diseases associated with urolithiasis. Based on the information from Gedangsari Primary Health Care medical record officer, 38 patients were suspected to having kidney stones in 2013. Based on those facts, this study was to analyze relation between the lime content wells water consumption and the incidence of urolithiasis in Gedangsari Subdistrict, Gunungkidul District.

\section{Method}

This study was qualitative and quantitative observational study in which data were collected cross sectionally. To collect data, in-depth interviews were performed using an interview guide containing questions about the risk factors of kidney stone disease and daily activities of the informants aged 30 years and older, and consuming water from wells in this area. To extract informant interviews, content analysis was used supported by triangulation.

This study was conducted in Gedangsari Subdistrict, Gunungkidul District, from July to September 2013. The study population was 3,849 wells in Gedangsari Subdistrict. Most of dig wells were located in Ngalang Village (1,430 wells) and the least was in Mertelu Village (68 wells). Sample size was 94 wells calculated by using proportional random sampling formula from Lemeshow. Samples from Ngalang Village were 35 wells, followed by Hargomulyo (25 wells), Serur (10 wells), Sampang (9 wells), and respectively Watugajah, Tegalrejo and
Mertelu (7, 6 and 2 wells).

This technique ensured the balance between the number of samples of each village with the population. Criteria for sample selection were that wells were used for drinking and having the depth at least 15 meters. Measurements of water hardness was performed by titration test in the Yogyakarta Health Laboratory, and based on National Standards Institute (NSI) procedure. Tools used were $25 \mathrm{ml}$ pippette, $100 \mathrm{ml}$ Erlenmeyer flask, turtles spoons and sample bottle. The materials used included $25 \mathrm{ml}$ distilled water, $25 \mathrm{ml}$ sample water, $\mathrm{NaOH}$, EBT indicator, standard EDTA 0.01 M solution. As quoted from BSN instructions, the working principle of this titration test was that the disodium salt of ethylene diamine tetra acetic (EDTA) will react with certain metal cathions to form soluble chelate complex compounds. At the $\mathrm{pH}$ of $10.0+0.1$, ions of calcium and magnesium in the sample will react with the Eriochrome Black T (EBT) indicator, and form a solution of purplish red. If $\mathrm{N}_{2} \mathrm{ED}$ TA is added as a titrant, the ions of calcium and magnesium will form complex compounds, molecular indicators of detaching, and to endpoint solution will change color from red to purple became blue. ${ }^{7}$

If the $\mathrm{CaCO}_{3}$ levels showing more than $300 \mathrm{mg} / \mathrm{L}$, then the water was categorized as high hardness water and low hardness if less than $300 \mathrm{mg} / \mathrm{L}$. Human population and sample were all citizens who consumed the wells water. Samples were 159 people who met the criteria, including those aged 30 years and older and consumed water from 94 well water samples. To know the informants' characteristics and disease history, in-depth interviews were performed using a questionnaire.

Interview results were written in manuscript form, then processed, summarized, analyzed and concluded. The residents selected as sampels were examined by the medical doctors to determine suspect urolithiasis with history-taking and physical examination. The statistics used for analysis was chi square test, to determine relation between levels of well water hardness and several other variables with incidence of suspect urolithiasis. Suspect urolithiasis is a condition in which a person is diagnosed by medical personnels (doctors) to have suffered from urolithiasis by clinical signs, so that requires supporting medical examinations, such as laboratory, x-rays or ultrasound examinations. However, this study did not conduct such examinations.

\section{Results}

The study results (Table 1) showed that 94 selected wells were consumed by 159 people as dominated by women. Around $99 \%$ of the respondents were residents who have lived more than 30 years in this area, and 10\% of these respondents were positively suspect urolithiasis. As many as $53 \%$ of the respondents consumed water less 
than 8 glasses per day and 15 of them positive suspect urolithiasis. As grouped into aged 30 - 60 years and older than 60 years, 4 of 54 respondents aged more than 60 years were positive urolithiasis. Wells water hardness level was measured by titration methods to get the lime content in the wells water to obtain hardness level. Hardness level was categorized into low, medium, high and very high.

Table 2 showed the chi square analysis result between water hardness, water consumption, length of stay, sex and age with the incidence of urolithiasis. Water hardness were related to urolithiasis with $\mathrm{RP}=2.27$, showing that high hardness of the water was a risk factor of urolithiasis. Those who consumed high hardness water were 2.27 times more likely to get suspect urolithiasis higher than those who consumed low hardness, although not statistically significant ( $p$ value $=0.26$ )

Analysis of water consumption with the incidence of

Table 1. Description of Respondents

\begin{tabular}{llcc}
\hline Variables & Category & Frequency $(\mathbf{n}=\mathbf{1 5 9})$ & $\%$ \\
\hline Sex & Male & 76 & 47.79 \\
\multirow{2}{*}{ Length of stay } & Female & 83 & 52.21 \\
& $>50$ years & 95 & 59.75 \\
Age & $\leq 50$ years & 64 & 40.25 \\
\multirow{2}{*}{ Drinking water habit } & $>60$ years & 46 & 28.93 \\
\multirow{2}{*}{ Water hardness level con- } & 30 - $\leq 60$ years & 113 & 71.07 \\
sumed wells & $\leq 8$ glasses & 69 & 43.40 \\
& high $(\geq 300)$ & 90 & 56.60 \\
& low $(<300)$ & 120 & 75.47 \\
\end{tabular}

urolithiasis, showed no relation $(\mathrm{RP}=0.98 ; \mathrm{p}$ value 1.00). Similarly, no relation was found between length of stay and urolithiasis incidence $(\mathrm{RP}=0.87 ; \mathrm{p}$ value $=$ 0.76). This study also showed no relation between age and incidence of suspect urolithiasis. Sex was found related to urolithiasis. Despite not statistically significant, male was found to have risk 1.40 times higher than women to get urolithiasis $(\mathrm{RP}=0.65$; $\mathrm{p}$ value $=0.43$ )

Multivariate analysis of all variables altogether as shown in Table 3 showed that the variables which had higher risk of urolithiasis incidence were hardness level and sex (Exp B = 2.63 and 1.29 respectively), although statistically not significant.

In-depth interviews with respondents showed that people have the local wisdom in managing drinking water, like precipitating and filtering the water before it was cooked.

The respondents' statements were illustrated below: "The water here is calcareous, However, I usually precipitate the water in the barrel for two days before cooking, drinking and is deposited again to avoid drinking the chalk."(Respondent1)

"We use well water here for drinking. Since it containe lime, before cooking usually I precipitate and filter the water to separate the chalk from the water..." (Respondent 2)

Another finding was that the local community did not have the habit of consuming water, as enhanced by one respondent's statement:

"I was not too fond of drinking water, drinking tea is

Table 2. Relation between Urolithiasis and Hardness Level of Well Water, Water Consumption, Length of Stay, Sex, and Age Group in Gedangsari Subdistrict

\begin{tabular}{|c|c|c|c|c|c|c|c|c|c|}
\hline \multirow{3}{*}{ Variable } & \multirow{3}{*}{ Category } & \multicolumn{4}{|c|}{ Urolithiasis } & \multirow{3}{*}{ Total } & \multirow{3}{*}{ Ratio Prevalence (RP) } & \multirow{3}{*}{ p Value } & \multirow{3}{*}{$95 \% \mathrm{CI}$} \\
\hline & & \multicolumn{2}{|c|}{ Suspect } & \multicolumn{2}{|c|}{ Healthy } & & & & \\
\hline & & $\mathbf{N}$ & $(\%)$ & $\mathbf{N}$ & $(\%)$ & & & & \\
\hline \multirow{2}{*}{ Water hardness level } & High & 14 & (11.6) & 106 & $(88.4)$ & 120 & 2.27 & 0.26 & $0.5-9.57$ \\
\hline & Medium & 2 & $(5.1)$ & 37 & $(94.9)$ & 39 & & & \\
\hline \multirow[t]{2}{*}{ Water consumption } & $\leq 8$ glasses & 9 & $(10.00)$ & 81 & $(90.00)$ & 90 & 0.98 & 1.00 & $0.39-2.51$ \\
\hline & $>8$ glasses & 7 & (10.14) & 62 & $(89.86)$ & 69 & & & \\
\hline \multirow[t]{2}{*}{ Length of stay } & $>50$ years & 9 & $(9.47)$ & 86 & (90.53) & 95 & 0.87 & 0.76 & $0.34-2.21$ \\
\hline & $\leq 50$ years & 7 & (10.94) & 57 & (89.06) & 64 & & & \\
\hline \multirow[t]{2}{*}{ Sex } & Male & 9 & (11.84) & 67 & $(88.16)$ & 76 & 1.40 & 0.48 & $0.55-3.59$ \\
\hline & Female & 7 & $(8.43)$ & 76 & $(91.57)$ & 83 & & & \\
\hline \multirow[t]{2}{*}{ Age group } & $\geq 60$ years & 4 & $(7.41)$ & 50 & $(92.59)$ & 54 & 0.65 & 0.43 & $0.22-1.91$ \\
\hline & $30-60$ years & 12 & (11.43) & 93 & $(88.57$ & 105 & & & \\
\hline
\end{tabular}

Table 3. Multivariate Analysis of Urolithiasis Incidence

\begin{tabular}{lllll}
\hline Variable & B & Exp B & p Value & 95\%CI \\
\hline Hardness level & 0.97 & 2.63 & 0.22 & $0.56-12.38$ \\
Length of stay & -0.34 & 0.71 & 0.69 & $0.14-3.72$ \\
Age & -0.67 & 0.51 & 0.35 & $0.12-2.12$ \\
Water consumption & -0.59 & 0.56 & 0.53 & $0.09-3.43$ \\
Sex & 0.25 & 1.29 & 0.64 & $0.43-3.87$ \\
\hline Constanta & 3.13 & 22.98 & 0.34 & \\
\hline
\end{tabular}


more frequent. I only drink water once or twice a day."(Respondent 1)

"I drink water whenever I want, but I could drink tea 6-7 cups a day." (Respondent 2)

\section{Discussion}

Well water is the main water source of the people in Gedangsari Subdistrict. Based on the laboratory examination, the lime or $\mathrm{Ca}(\mathrm{OH})_{2}$ content in the water of this area varied. Moderate level was $24 \%$, high was $42 \%$ and very high level was $34 \%$. The limestone structure that made up the region was allegedly the reason for the high lime content of wells water, and it was in line with the statement that main source of hardness was limestone and dolomite. The ground water will be hard easier than superficial water. ${ }^{1}$ This statement also confirmed that there was a negative correlation and positive hardness by stone formation. ${ }^{8}$ In line with this is a statement saying that thick top soil layer and limestone presented in the area will have high water hardness. ${ }^{9}$ In the contrary, if the area is located in the place with thin soil layer and lime stones, then will probably give low hardness.

Hardness can be seen in an area where limestone and rock are found in a big amount. ${ }^{10}$ The length of contact between groundwater with the rocks would affect the size of the dissolved minerals. The longer the groundwater in contact with the rock, the higher the elements dissolved in the water. ${ }^{11}$ Similar to the water from the wells in the limestone area, the longer the calcareous rocks in contact with the ground water calcareous rocks, the higher the lime content in the water.

Based on the findings, it seemed that the hardness spread evenly throughout the study area. Although wells water hardness level in Gedangsari Subdistrict is still below the standards set by Health Ministry of the Republic of Indonesia (Decree No. 907/Menkes/SK /VII/2002, that is $\leq 500 \mathrm{mg} / \mathrm{L}$ ). However, this is feared to trigger health problems to people who long term consume the water, such as kidney stones or urinary tract stones. ${ }^{12}$ This is in line with study findings stating that composition of calcium in the urine was one reason of urinary tract stone formation. ${ }^{13}$

From the observations and interviews to the respondents, $79 \%$ of the cooking place had precipitated chalk (limestone sediment). The limestone sediment indicated that the water contained lime or hard water. Hard water is harmless, but it can cause quite serious problems in a long term. In addition, the turbidity of the water can reduce the physical quality of drinking water as in accordance with the Decree of Health Minister of the Republic of Indonesia that water consumed must meet the established standards to prevent health problems. ${ }^{12}$

Multivariate analysis showed relation between well water hardness and suspect urolithiasis $(\operatorname{Exp} B=2.63$; $p$ value $=0.22$ ), which means that the high water hardness level would have 2.63 times higher risk than the moderate level, although statistically not significant. Water hardness level in Gedangsari Subdistrict was high, but not many residents experienced suspect urolithiasis. This might be because most people had already managed by precipitating, filtering the water in advance before consuming.

Such a local wisdom practiced by the local people is suspected to bring about some variables did not significantly influence urolithiasis. This showed that although the theoretically some variables had risk the occurrence of suspect urolithiasis, but the local people treatment to the water had lowered the risk of urolithiasis. Water hardness can be lowered by heating. Water containing $\mathrm{Ca}\left(\mathrm{HCO}_{3}\right)_{2}$ and $\mathrm{Mg}\left(\mathrm{HCO}_{3}\right)_{2}$, when heated will precipitate the $\mathrm{CaCO}_{3}$ and $\mathrm{MgCO}_{3}$ compound.4,13

Based on the interview, most respondents practiced a local wisdom (treatment), among others, by precipitating and filtering the water prior to consumption, aiming to lower the lime content. Although statistically not significant, it was suspected as the cause of the relation between water hardness and urolithiasis. Aside from the local wisdom, water hardness value was still below the recommended maximum limit according to the World Health Organization (WHO), that is less than $500 \mathrm{mg} / \mathrm{l}$. It also affected the incidence of urolithiasis because it could slow the formation of kidney stones in the body.

Filtering water before consuming is good practice in lowering the water hardness. One of the materials that can be used to lower the hardness is zeolite stone, that could lower water hardness based on screening study. 14 The most effective medium for lowering hardness level of the well water is a $70 \mathrm{~cm}$ thickness combination of of zeolite and activated charcoal. ${ }^{15}$ The respondents carried out filtering in several ways, such as by installing fabric at the end of the faucet, using filter tools purchased in the market, and there were people using charcoal and zeolite stone. Although the well water lime content of the respondents'wells were still below the recommended level, but this was still necessary to be worried because it remained a risk factor for the occurrence of kidney stones. If the composition of calcium in the body is constantly increasing, then stone may be formed in the urinary tract, despite in a relatively long time. This is because of the hardness of water is less than $500 \mathrm{mg} / \mathrm{l}$, compared to the people who consume water hardness $500 \mathrm{mg} / \mathrm{l}$ and over. These results indicated that there were two respondents $(5.1 \%)$ who used to consume water with medium hardness and suspect urolithiasis.

The respondents with high water hardness had 22.96 times higher risk to get the kidney stone disease than those with water that met the requirements. In the statistical test, risk estimate calculation was found for OR = 
22.97 (OR > 1), within 95\% confidence level (CI) $(4.796$ to 110.002$).{ }^{16}$ A study conducted by Sulistiyani, ${ }^{17}$ found that OR was 5.916, meaning that the respondents whose water hardness level did not meet the requirement would be 5.916 times at risk of kidney stone disease compared to whose water hardness levels met the requirement.

In this study, the risk factors studied were hardness level of well water, water consumption, age, length of stay (residing) and sex. However, there were other risk factors that were not studied, among others, records of hypertension and diabetes mellitus. This is in line with studies that stated that untreated hypertension could cause other organ failure such as kidney. ${ }^{18}$ Of all the above discussed factors, the hardness level of well water, water consumption, age, length of stay and sex were not significantly related. But when referred to the prevalent ratio (PR), water hardness RP was 2.27 and sex was 1.40 .

It shows both variables were risk factors of urolithiasis. In theory, gender is one of risk factors of kidney stone. Men are more susceptible to kidney stones for several reasons, such as men have narrower ureter tract than women, men have higher intensity activity that risk dehydration and lastly women have kidney stone growth inhibiting hormone. ${ }^{19}$ Urolithiasis incidence among women in this study was not much different than among men, causing relation between sex with urolithiasis incidence was not statistically significant. Water consumption was suspected to be one of the risk factors that affected suspect urolithiasis among people in Gedangsari Subdistrict. Of 16 suspect cases, 9 of them claimed they consumed water less than 8 glasses per day. Less water intake causes an increase in plasma osmolality and decrease in effective arterial volume, resulting decrease in urine volume and natrium excretion. ${ }^{20}$ Decreasing urine volume may uplift solute concentration in the urine and increases the formation of stones. This finding is supported by Izhar, ${ }^{7}$ study $(\mathrm{OR}=4.3)$, who found that respondents having a habit of drinking less than 1.5 liters/day or 8 glasses per day had a risk of calcium oxalate sediment 4.3 times compared to those who drank more. It is encouraged to consume water more than 2 liters per day or equivalent with 8 glasses per day. ${ }^{21}$

Stone formation can be prevented by drinking plenty of water (8-10 cups/day), as well as reducing consumption of food and beverage that are rich of oxalates, such as spinach and tea that can lead to calcium stone formation. ${ }^{16}$ This is in line with the theory, that oxalate comes from the body (endogenous), food eaten and from the vitamin C metabolism, will generally form crystals that cause kidney stone disease. ${ }^{16}$ When the urine becomes oversaturated with materials that are not dissolved like calcium, uric acid, oxalate and cystine, and because of the exessive level of excretion, or because of extreme water savings, the minerals in urine sediment that causes crystallization, may be then developed and united to form the stone. 22

From analysis of relation between length of stay and urolithiasis, this study found that there was no relation between the length of stay and the incidence of urolithiasis $(\mathrm{RP}=0.87 ; \mathrm{p}$ value $=0.76)$. Most of the respondents in this study had lived in this area for a long time. Only 2 $(1.26 \%)$ respondents have stayed less than 10 years. Statistically, there was no relation between length of stay and the occurrence urolithiasis suspect.

No relation was found between age and the incidence of urolithiasis ( $\mathrm{RP}=0.65$; $\mathrm{p}$ value: 0.43 or Exp-B $=0.51$ Sig $=0.35)$. In general, the age factor may influence the occurrence of urolithiasis, because the function of the organ at the age of 50 years and over began to decline. In this study, the incidence of suspect urolithiasis was measured by age from 30 years to older than 60 years. Urolithiasis was more expected to happen among people older than 65 years. The results showed a significant difference between urolithiasis among those aged 65 years and older than those younger. ${ }^{23}$ However, this study showed different results. The highest percentage of suspect urolithiasis was at the age of 30 - 60 years, despite the difference in incidence with the age older than 60 years was not significant.

Another risk factors that may associate with the incidence urolithiasis was hypertension, but this risk factor was not investigated in this study. This variable may influence the incidence of urolithiasis, in line with study findings that stated untreated hypertension could cause organ failure including kidney. ${ }^{18}$ Diabetes mellitus and hypertension are diseases common among patients with urolithiasis. There were significant differences between both diseases and incidence of urolithiasis among patients aged 65 years and older compared to the younger.

\section{Conclusion}

There is relation between water hardness and sex with incidence of urolithiasis, but not statistically significant. However, there is no relation between water consumption, length of stay and age with incidence of urolithiasis in Gedangsari Subdistrict, Gunungkidul District, Yogyakarta. This is probably because of people's habits in treating drinking water through precipitation or filtration before cooking.

\section{Recommendation}

The local health authority should follow up the diagnosis of suspect urolithiasis, and socialize lime content water treatment and processing by precipitating and filtering the water before consuming, aside from advising people to accustom drinking proper water daily.

Further studies should measure the levels of water 
hardness by measuring water hardness after sedimentation or filtration stages, instead of measuring the water directly from the wells. Also suggested in the further to involve other confounding variables, such as hypertension, diabetes, and others.

\section{References}

1. Sengupta P. Potential health impact of hard water. International Journal of Preventive Medicine [serial on internet online]. 2013 [cited 2015 Feb 6]; 4 (8): 866-75. Available at from: http://www.ncbi.nlm.nih.gov/pmc/ articles/PMC3775162/\#! po=6.25000.

2. Siener R, Hesse A. Fluid intake and epidemiology of urolithiasis. European Journal of Clinical Nutrition. 2003; 57 Suppl 2: S47 - 51.

3. Fink HA, Akorner JW, Garimella PS. Diet, fluid, or supplements for secondary prevention of nephrolithiasis: a systematic review and metaanalysis of randomized trials. European Urology. 2009; 56 (1): 72-80.

4. Said NI. Teknologi pengelolaan air minum: teori dan pengalaman praktis. Jakarta: BPPT; 2008.

5. Chandra B. Pengantar kesehatan lingkungan. Jakarta: Penerbit EGC; 2012.

6. Nurullita U, Astuti R, Arifin M. Pengaruh lama kontak karbon aktif sebagai media filter terhadap persentase penurunan kesadahan $\mathrm{CaCO}_{3}$ air sumur artetis. Jurnal Kesehatan Masyarakat. 2010; 6 (1): 48-56.

7. Badan Standardisasi Nasional. Air dan Air Limbah - Bagian 12: cara uji kesadahan total kalsium $(\mathrm{Ca})$ dan magnesium $(\mathrm{Mg})$ dengan metode titrimeter. Jakarta: Badan Standarisasi Nasional; 2004.

8. Giannossi ML, Summa V. An observation on the composition and recurrence of urinary calculi: environmental influence. In: Censi P, Digrah TH, Erel Y, editors. Medical Geochemistry Geological Materials and Health. Az Dordrecht: Springer Netherland; 2013. p. 67 - 90.

9. Effendi H. Telaah kualitas air: bagi pengelolaan sumber daya dan lingkungan perairan. Yogyakarta: Kanisius; 2003.

10. Astuti Y, Suprihanto. Pelunakan soda kapur dengan rekarbonasi untuk menurunkan kesadahan dan nilai LSI air bribin Gunungkidul. Bandung: Program Studi Teknik Lingkungan, Fakultas Teknik Sipil dan Lingkungan, Institut Teknologi Bandung; 2009.

11. Murtianto H. Bentuk lahan sebagai dasar penyusunan hidromorfologi. Bandung: Jurusan Pendidikan Geografi Universitas Pendidikan Indonesia; 2011.

12. Kementerian Kesehatan Republik Indonesia. Syarat-syarat dan pengawasan kualitas air minum. Jakarta: Kementerian Kesehatan Republik Indonesia; 2002.

13. Izhar M, Haripurnomo K, Darmoatmodjo S. Hubungan antara kesada- han air minum, kadar kalsium dan sedimen kalsium oksalat urin pada anak usia sekolah dasar. Berita Kedokteran Masyarakat. 2007; 23 (4): $200-9$.

14. Mifbakhuddin, Wardani RS, Rozaq A. Pengaruh ketebalan diameter zeolit digunakan sebagai media filter terhadap penurunan kesadahan air sumur artetis di Kelurahan Sendangguwo Kecamatan Tembalang Kota Semarang. Jurnal Kesehatan Masyarakat Indonesia. 2009; 4 (2): 20009.

15. Ristiana N, Astuti D, Kurniawan T. Keefektifan ketebalan kombinasi zeolit dengan arang aktif dalam menurunkan kadar kesadahan air sumur di Karangtengah Weru Kabupaten Sukoharjo. Jurnal Kesehatan. 2009; 2 (1): 91 - 102.

16. Krisna D. Faktor risiko kejadian suspect penyakit batu ginjal dan saluran kemih di Kabupaten Kulon Progo Yogyakarta [skripsi]. Semarang: Universitas Negeri Semarang; 2011.

17. Sulistiyani, Budiyono, Budi A. Analisis faktor risiko kejadian batu ginjal dan saluran kemih di Kabupaten Kulonprogo Yogyakarta. Jurnal Profesi Medika. 2007; 7 (1): 1 - 11.

18. Amran Y, Febrianti, Irawanti L. Pengaruh tambahan asupan kalium dari diet terhadap penurunan hipertensi sistolik tingkat sedang pada lanjut usia . Kesmas: Jurnal Kesehatan Masyarakat Nasional. 2010; 5 (3): 12530.

19. Anwar F. Pria lebih mudah kena batu ginjal ketimbang wanita, ini alasannya. Detik Health [online]. 2014 [cited 2015 March 25]. Available from: http://health.detik.com/read/2014/12/11/ 191552/2775043/763/pria-lebih-mudah-kena-batu-ginjal-ketimbangwanita-ini-alasannya?1991101755.

20. Rully S. Batu staghorn pada wanita: faktor risiko dan tata laksananya. Jurnal Ilmiah Mahasiswa Kedokteran Indonesia. 2010; 1 (1): 52 - 8.

21. Wahap S, Setiani O, Joko T. Hubungan kandungan mineral calcium, magnesium, mangan dalam sumber air dengan kejadian batu saluran kemih pada penduduk yang tinggal di Kecamatan Songgom Kabupaten Brebes. Jurnal Kesehatan Lingkungan Indonesia. 2012; 11 (2): 166-71.

22. Bahdarsyam. Spektrum bakteriologik pada berbagai jenis batu saluran kemih bagian atas. Medan: Bagian Patologi Klinik, Fakultas Kedokteran Universitas Sumatera Utara; 2003.

23. Arampatzis S, Lindner G, Irmak F, Funk G, Zimmermann H, Exadaktylos A. Geriatric urolithiasis in the emergency department: risk factors for hospitalisation and emergency management patterns of acute urolithiasis. BMC Nephrology [serial on internet]. 2012 [cited 2015 jun 6]; 13 (117): 1-6. Available from: http://www.biomedcentral.com/14712369/13/117. 